'A Mysterious Music in the Air: Cultural Origins of the Loudspeaker'

DRAFT OF ARTICLE PUBLISHED IN Popular Music History (2014)

Kyle Devine

Department of Music

City University London

A129 College Building

Northampton Square

London EC1V 0HB

+44(0)20 70408283

kyle.devine.1@ city.ac.uk

\title{
Bio
}

Kyle Devine is Lecturer in Music at City University London and a consultant to the Music and Digitization Research Group at the University of Oxford. This is the second in a suite of three articles on the musical and cultural history of loudness. The first, a critical history of the 'loudness wars', appeared in Popular Music. The third, on the intellectual history of the decibel, is forthcoming. He is also co-editing two books: Living Stereo: Histories and Cultures of Multichannel Sound (Bloomsbury) and The Sociology of Music Reader (Routledge). 


\section{A Mysterious Music in the Air: Cultural Origins of the Loudspeaker}

Loudspeakers are everywhere in the built environment. Indeed, music, sound, and listening today are arguably defined by their apparently inevitable mediation by an electronically amplified loudspeaker. But it wasn't always so. When and how did that transformation take place? What was its musical and cultural significance? Whereas popular and historical accounts tend to emphasize the concentricity of the loudspeaker and rock music, this article roots such developments in an essential but under-researched prehistory, showing how the loudspeaker went from an incredible novelty to a predictable ubiquity between 1915 and the 1930s. I sketch the loudspeaker's early history and offer an assessment of its role in twentieth-century musical and acoustic culture. I suggest that the loudspeaker needs to be understood as cultural technology in a broader history of sound, and that it played a central role in the formation of modern listening.

Keywords: loudspeaker; sound reproduction; loudness; volume; amplification; public address; listening formation; sound studies; cultural history

\section{Introduction}

From the phonograph to the MP3, sound recording is now considered 'arguably the most significant change to have affected music in the twentieth century' (Clarke 2007: 47).

Undeniably, the ability to record sound and play it back - phonographic mediation - has influenced not only how music is bought and sold, but also how music is composed, performed and heard, and how it works to foster senses of community and self (Attali 1985; Martin 1995; Frith 1996; Kenney 1999; Born and Hesmondhalgh 2000; Sterne 2003; Frith and Marshall 2004; Cook et al. 2009; Maisonneuve 2009). As a concept, 'phonography' is virtually its own subgenre of cultural theory (Eisenberg 1987; Mowitt 1987; Adorno 1990; Rothenbuhler and Peters 1997; Engh 1999; Kittler 1999; Gitelman 2000; Lastra 2000; Sterne 2003; Middleton 2013). Phonography has even generated philosophical dispute about music's very being (Talbot 2000; Born 2005; Kania 2008; Matheson and Caplan 2011). Clearly, the significance of phonographic mediation should not be underestimated. ${ }^{1}$

Yet underlying a century of shifting phonographic recording formats, playback devices and media systems (and cutting across the original-copy and recorded-live distinctions that have informed theoretical debate around these issues ${ }^{2}$ ) there has been a remarkable constant: the electronically amplified loudspeaker. Whether or not listeners are reflexively aware of this reality, the inevitability of the loudspeaker has shaped the aesthetics and experiences of twentieth-century music and sound, from gramophones to ringtones and concert halls to dance floors (Théberge 2001; Gopinath 2013; Thompson 2002; Henriques 2003). The loudspeaker has also quietly but profoundly influenced the development of music industries and media systems, in terms of both technological infrastructure and professional expertise (Gomery 2005; Wurtzler 2007). It has played a central role in reconfigurations of domestic space and the workplace,

\footnotetext{
${ }^{1}$ However, for a critique that the historiography of sound reproduction has over-emphasized phonographic mediation, see Devine (2013).

${ }^{2}$ For details of these critiques, including also the common media-instrument and transmission-storage distinctions, see Sterne (2003; 2007; 2012).
} 
architecture and urban planning (Keightley 1996; Korczynski and Jones 2006; Thompson 2002; Bijsterveld 2008). Loudspeakers are also implicated in the politics and ethics of listening, in the construction - and obstruction - of acoustically mediated forms of identity, whether individual or collective, public or private, imagined or assembled (Johnson and Cloonan 2008; Goodman 2010; Cusick 2013). Indeed, around the world and through the seven seas, the loudspeaker has played a vital role in sculpting the cultural geography of an uneven but global acoustic modernity (Lee 1999; Dolan 2008; Hirschkind 2006; Radovac 2011; Sewald 2011; Eisenberg 2013; Shiga forthcoming). The ubiquity of the electrically amplified loudspeaker — its centrality in mediating so many relationships with sound and music - suggests that this technology defines the twentieth century as a listening experience.

It is striking, then, that in most histories of music, sound and media the loudspeaker is taken for granted, 'made invisible by its own success' (Latour 1999: 304). However, in going back to the earliest days of the loudspeaker it becomes apparent that most of what is now taken for granted about electronically amplified sound was at first unclear to professionals, musicians and audiences. For example, when in 1915 Peter Jensen demonstrated some of the first amplification systems, the Magnavox loudspeaker was astonishing: there are reports of incredulous investors refusing to back the apparently impossible invention, of navy sailors dancing to a seemingly sourceless and therefore 'mysterious music in the air', of innocent bystanders who 'thought the world was coming to an end and scrambled for cover' (Jensen 1975: 90-92; Klapholz 1984: 33; Coodley 2007: 57). ${ }^{3}$ Incidents such as these serve as reminders that the loudspeaker and its listening practices are not natural but, rather, became naturalized through processes of history and culture.

For most commentators, though, it is the rock era, not the early twentieth century, that is the more obvious place to begin the work of assessing the loudspeaker's historical and cultural significance. Sound engineer Stephen Court (1984: 72): 'If any doubt exists as to just how popular music began', he says, 'look at the history of music sound reinforcement and consider that the start of it represents the beginning of rock music as we know it'. Indeed, the mythology of rock suggests that the salience of the amplified guitar in 1950s rock 'n' roll marks the moment when music 'became electric' (Lydon 1974). From this perspective, the mass appeal of guitar groups then had a crescendo effect in musical culture: amplified bands allowed for larger venues, which had larger and therefore noisier audiences, which led to louder bands and still larger venues, which eventually called for the amplification of drum sets and the re-amplification of electric guitars, and so on. ${ }^{4}$ By the 1970 s, loudspeakers were powerful and sophisticated enough to facilitate huge outdoor music festivals such as Woodstock, new genres such as arena rock, and new connections between loudness and 'authenticity' in heavy metal and punk (Waksman 2009: passim; Percival 2011). Loudness had become firmly a part of rock aesthetics and ideology, and the business of amplification equipment was booming (Majeski 1990; Duncan 1996). Indeed, the

\footnotetext{
${ }^{3}$ Although not the focus of this article, accounts of astonishment in relation to modern technology cannot be take at face value. Gunning (1989), for example, has argued that early cinema audiences were not naively terrified by the realism and credulity of film, but knowingly amazed by its artifice and incredibility. Something similar was surely going on in the case of the loudspeaker.

${ }^{4}$ For a critique of such whiggish models of the history of loudness, see Devine (2013).
} 
research team studying the history of live music in the UK has argued that pre-1970s musical culture was characterized by an 'absence ... of ancillary industries' such as live sound equipment and engineering, and that such industries only became professionalized in step with the rise of rock (Frith et al. 2010: 5, 7).

The histories of rock music and the loudspeaker do share a special aesthetic, social and economic concentricity. However, rock-centred accounts not only overlook the centrality of the loudspeaker in a variety of other mid-century musical cultures, from reggae (Henriques 2011) to the avant-garde (Piekut 2011). They also downplay various ways in which the uses of the loudspeaker in rock can be seen as extensions of previously established technological, cultural and aesthetic conventions, as the case of Jensen's Magnavox suggests.

As a challenge to rock mythology, then, and as a complement to scholarship focused on mid-century developments, this article shows how the loudspeaker went from an incredible novelty to a predictable ubiquity between about 1915 and 1940. The reason for telling the story of when this old technology was new (Marvin 1988) is partly to fill a gap: unlike other key twentieth-century musical instruments, sound technologies and media systems (Théberge 1997; Waksman 1999; Pinch and Trocco 2002; Wurtzler 2007; Downes 2010; Osborne 2012; Sterne 2012), there is no detailed musical and cultural history of the loudspeaker. More specifically, though, I want to examine how the loudspeaker became so prevalent, how uses of and attitudes toward the loudspeaker took shape. Technological innovations tend to create turbulence in music history (Pinch and Bijsterveld 2003) and the introduction of the loudspeaker exposes some deeply held but unspoken values in musical culture. The early history of the loudspeaker thus instances the co-formation of music technology and musical culture, and opens a window onto a time when the contemporary acoustic environment was taking shape. This article recovers some of the cultural, musical and epistemological processes through which the loudspeaker became central to twentieth-century music and modern listening.

I begin by historicizing and theorizing the loudspeaker as a technology of sound reproduction. I then move on to describe the various uses of public address systems through the 1920s, especially in the context of political campaigns and questions about the loudspeaker's potential to reconfigure listening formations at the level of the national 'acoustic community'. Finally, I sketch the loudspeaker's rise to ubiquity in musical culture through the 1930s, focusing on the jukebox, the PA and the electric guitar in the world of popular music, and also touching on the experimental art music collaborations between Leopold Stokowski and Bell Laboratories. As with the pre-rock establishments mentioned above and explored below, the Stokowski episode can be seen as a foundational set of negotiations that prefigured later technological, aesthetic and cultural settlements surrounding the loudspeaker in the musical avant-garde. The work of this article thus calls for an approach that welcomes the insights that can be gained when popular music is studied alongside various forms of art music and acoustic mediation, as overlapping phenomena in a shared history of sound and listening. My conception of popular music studies is therefore open, and the discussion that follows will freely draw the field into conversations with musicology, sound studies, media studies, cultural sociology, and science and technology studies.

\section{The Loudspeaker as a Technology of Sound Reproduction}

The loudspeaker did not emerge out of the blue. It does not have an individually specifiable origin and did not become a static or singular object after its invention. Indeed, probably all 
cultures have confronted the need to amplify sound. For most of history, the solutions to this problem were physical. Consider, for example, voice projection and visual augmentation in ancient amphitheatres, architectural acoustics in Renaissance churches, Enlightenment-era speaking trumpets, as well as nineteenth-century inventions such as the saxophone and turn-ofthe-century developments in gramophone horns and pneumatics. ${ }^{5}$ These devices are part of what Mara Mills (2009) calls the 'long history of loud-speaking'. However, the loudspeaker proper marks a line in that history's sand; it is distinguished from previous devices in that it vibrates the air in response to an electrical input. Even that definition is still very broad, though, covering devices ranging from the earliest telephones to contemporary developments in nanotechnology. The type of amplification under consideration here, which is the basis of most modern loudspeakers, is defined by the moving electromagnetic coil principle as it developed after the invention of the electronic vacuum tube, particularly in the work of Peter Jensen in the 1910s, and Chester Rice and Edward Kellog in the 1920s. But since this is not a cones-and-coils organology of loudspeaker, many of these technical details are a footnote to a more general discussion. ${ }^{6}$

From the perspective of this article, the loudspeaker only becomes meaningful as part of a larger set of technologies and cultural practices. This includes recording formats and playback devices, microphones and instruments, vacuum tubes and transistors, forms of signal processing and transmission - a technological complex that we might call an assemblage of transduction. Jonathan Sterne (2003: 22) defines transduction as a process by which sound is 'turn[ed] into something else and that something else [is turned] back into sound'. But transduction is not just mechanical; it is a deeply cultural artifact (ibid.). As such, this article also focuses on the cultural actions and conditions that subtend the tools of transduction. Together, this assemblage of transduction and its correlated acoustic precepts and practices constitute an emulsion that we might call a 'listening formation'. An examination of this listening formation provides the backdrop against which the loudspeaker assumed its musical and cultural significance.

Christopher Faulkner (1994: 65) originally defined a listening formation as 'the whole context of audition for historically specific audiences, taking account of expectations formed for them by the whole culture and technology of speech and hearing of which they are a part'. Extending his conceptualization, we can say that listening formations account for the affordances of both obvious objects (such as loudspeakers) and less visible materialities (such as sound waves) in relation to both the ontogenesis and phylogenesis (Bourdieu 1996) of acoustic subjectivities. These sociohistorical material and affective relations are understood to be

\footnotetext{
5 Two prominent pneumatically amplified devices were Charles Parsons' Auxetophone and Thomas Edison's Aerophone. The imagined uses of Edison's compressed-air amplifier ranged from the benign ("signaling distant vessels") to the ridiculous (giving voice to the Statue of Liberty). For more on the Aerophone, see anon. (1878a) and anon. (1878b). On other physical means of amplification, see for example Schmidt (2000), Blesser \& Salter (2007), Howard \& Moretti (2009), Cottrell (2012).

${ }^{6}$ The possibility of electrical sound amplification relies on many ideas and technologies that predate the loudspeaker (see Hunt 1954). Additionally, the loudspeaker is not a static object; it has sustained a variety of materials and principles, uses and abuses (Wilson 1929; Beranek 1954; Klapholz 1984; Borwick 2001; Eargle 2003; Newell and Holland 2007). See also the famous paper by Rice \& Kellog (1925).
} 
generated within certain systems of thought, to circulate within particular institutional arrangements, and to be forged into and through certain configurations of social action and public order (cf Latour 2005; Bennett 2007; Straw 2010; Born 2011). ${ }^{7}$ The loudspeaker illustrates these dynamics, given that its invention involved the convergence of a particular scientific epistemology with an emergent institutional arrangement - a convergence that both relied on and shaped a historically specific understanding of the relationship between sound technology and listening subject.

In constructing and operating the earliest public address systems, from the 'rough-andready lash up' of Fred Warren in the UK (anon. 1963: 8; cf Warren 1965) to the widely publicized demonstrations by various contingents of the Bell System in the US (Green and Maxfield 1923), one of the primary goals was to conceal the work of the loudspeaker. Indeed, while much of the reportage surrounding the first loudspeakers focused on the spectacular and sensational aspects of electrically amplified sound - 'Lincoln's Gettysburg Address reverberating through the air like the roar of a giant! A piano solo resembling the chimes of Westminster Abbey played by the Colossus of Rhodes!' (anon. 1915) — public address engineers espoused a cooler rhetoric of control, naturalness, transparency. In the words of Western Electric (ca. 1922): 'Ideal conditions obtain when the audience is unaware of the loud speaking equipment and is of the impression that it hears the words of the speaker direct'.

But concealing the work of the loudspeaker was counterintuitive. Although engineers aimed for transparency, they discovered that the logical solution to this problem (mimicking a speaker's voice and an audience's conditions of audition by projecting the full range of frequencies from a single loudspeaker) created a sound which 'the listener believes . . . is badly distorted' (Eccles 1929: 237). Instead, engineers found that the 'frequency-sensitivity of normal ears' (Fletcher and Wegel 1922) allowed them to focus not on the full frequency spectrum but on the range of sound 'which is most essential to intelligibility' (Cameron 1936: 260), while the psychology of sound localisation encouraged them to divide 'the amplified speech currents among a number of well-distributed loud speakers' (Eccles 1929: 237). In constructing loudspeakers and sound systems, engineers thus created a system of representation and mediation that took into account not just the technical capabilities of their equipment, but also the perceptual capabilities of their listeners - perceptual capabilities which were understood to be both physically imperfect and psychologically strategic.

The conception of hearing at the root of these practices came from two fields: the acoustic sciences and telephony. From the mid nineteenth century the acoustic sciences ${ }^{8}$ were based in an epistemological distinction between subject and object which accepted that the physics of sound in the air exist in an indirect and complex relationship with the sensation of

\footnotetext{
${ }^{7}$ In this sense, listening formations are neither rigid nor homogeneous: they account for inertia and impetus, normative conventions and departures from them. Indeed, 'formation' here designates an ongoing dynamic of structure and process, in which various practical and conceptual orientations toward sound are collocated but not necessarily integrated, held together by magnetisms of incongruence. ${ }^{8}$ The 'acoustic sciences' can be thought of as a constellation of disciplines including the physics of sound, the physiology of the ear, the psychology of hearing, as well as musicology and music theory, which participates in processes of objectivation and subjectivation similar to those described by Foucault (1970) more generally in terms of the 'human sciences'. The archaeology of the acoustic sciences especially the intellectual history of the decibel - are topics that I pursue in another essay.
} 
sound in the ear. Telephone researchers harvested the instrumental fruit of this epistemological distinction by eliminating speech frequencies deemed inessential to intelligibility in the interest of reducing the bandwidth of a signal - which increased the cost-effectiveness of the telephone system by allowing multiple signals to be transmitted through a single cable (cf Fagen 1975; Sterne 2012). In this way, the construction of the telephone system was based in a normalized conception of the listening subject that was forged through a particular conjunction of scientific epistemology and industrial capitalism (Sterne 2012: 41ff). Through a similar understanding of relationships between the frequency range of the loudspeaker and the frequency response of 'normal ears', on the one hand, and between speaker placement and the psychology of localisation (cf Boring 1942: 381ff), on the other, the loudspeaker sound system is also configured according to the capacities and limitations of a normative listening subject. Loudspeakers and sound systems can be 'concealed' because they exploit these capacities and limitations of the 'mind's ear' (Sterne 2013).

Within a listening formation, the loudspeaker and the listener are thus attuned to one another. As Sterne (2006) has argued with regard to the psychoacoustic logic underlying the MP3, loudspeakers and sound systems work because they 'play' the listener as much as they play sound. Indeed, there is a dynamic between the loudspeaker and the loudspoken that participates in the same perceptual technics and political modulations described by Sterne $(2012 ; 2013)$ in relation to the MP3. The loudspeaker can thus be understood as part of a broader history in which particular sets of problems in scientific epistemology and industrial capitalism fused around the turn of the twentieth century, giving rise to a specifically modern conception of acoustic subject-object valences. This is one of the main lessons of sound studies: sound technologies and acoustic subjectivities consist in their mutual modulation. If this is the general sense in which the loudspeaker has played a significant role in the formation of modern listening, it has also been involved in specific ideological debates, material reconfigurations and aesthetic transformations in twentieth-century musical and acoustic culture.

\section{The Advent of the Loudspeaker and the Publics of Public Address}

Many of the first uses of the loudspeaker amounted to novelty. For example, as an extension of one of the earliest and farthest-fetched uses for public address systems (a means of air-traffic control; see Pridham 1918; Jensen 1975: 110-111) and as a precursor to more sinister uses (a means of crowd control; see Johnson and Cloonan 2008: 57), Peter Jensen and Edwin Pridham's Magnavox was explored for its use in airborne advertising: 'An aviator three thousand feet in the air said, "Buy a bond!" and crowds of people ... heard him plainly' (anon. 1919: 81). Scientists were enthralled with the ability of electrical amplification to act as an acoustic microscope, bringing previously unheard atomic sounds within earshot (anon. 1924a; anon 1924c). In California there was a loudspeaker large enough to be used as a seven-person diving platform (anon. 1922a), while a New Jersey City Hall was outfitted with a sound system so large that the whole town could hear it, so powerful that 'a visitor's clothes flap in time to the music, and entering the tower containing the strongly vibrating air is like walking through mud' (anon. 1931a: 68).

Despite gimmicks such as these - though surely also in a way because of them loudspeakers and public address systems took permanent root in an array of contexts through the 
1920s: from schools to pools (Glover 1931; anon. 1922a), steamships to stadiums (Cameron 1936: 259; anon. 1926b), churches to courtrooms (anon. 1921a; anon. 1926a), workplaces to warning systems (Mitchell 1931: 9; Lane 1922), restaurants to racetracks (Cameron 1936: 264; Adams 1987: 9). Indeed, from the National Air Races to the Indianapolis 500, loudspeakers announced pole positions and ordered drivers to start their engines. One of the earliest and most noticeable uptakes of electrical amplification, though, was in politics, where the technology received almost as much coverage as the figures that used it.

Woodrow Wilson, for example, whose poor health had limited his public speaking engagements, was able to continue addressing large outdoor crowds thanks to a custom system developed by Magnavox in 1919 (Jensen 1975: 114ff). A similar system was used in 1920, during Democratic nominee James Cox's campaign efforts (anon. 1920a; anon 1920b). In other cases, loudspeakers were attached to vehicles and used to blare advertisements and political messages through neighbourhoods and across the country (anon. 1922b). Indeed, loudspeakers were still news in Calvin Coolidge's term (anon. 1925).

Perhaps most famous, though, were Warren Harding's inaugural speech and his funeral oration to the Unknown Soldier on Armistice Day, both in 1921. Partly, Harding's inaugural speech was remarkable for demonstrating that a public address system made for orderly oratory:

There was none of the crowding cruelty which maims and sometimes kills the woman or child who is caught in the press of an unthinking crowd. The newspapers of Washington had told their readers that the voice would be distributed all over the plaza and the park, and naturally there was no great rivalry for front positions. (anon. 1921b: 3; cf Dooley 1932: 14)

Commentary on Harding's funeral oration went further, concerning itself less with the ability of the loudspeaker to civilize the crowd, and more with its ability to foster new listening formations at a level that R. Murray Schafer (1994: 215) calls the acoustic community.

Echoing Plato, early commentators recognized that 'Public speaking occupies a place of paramount importance in the conduct of a democratic form of government' (Western Electric ca. 1922). However, the increasing American population, and the increasing urbanization of that population, 'prompted some to predict the passing of the art of public expression which had been diligently studied and faithfully practiced for many centuries' (ibid.). The electronically amplified loudspeaker apparently solved this problem, allowing Harding to address 'the greatest number of people that has ever listened to one man's voice at one time in the history of the world' (anon. 1921b: 1; cf anon. 1920c). This expansion of the acoustic community was said to mark 'an epoch in communication' (anon. 1921d: 30-31), 'a new day in the psychology of the spoken word' (anon. 1921b: 2; cf Green and Maxfield 1923: 75).

During this period of post-War re-stabilization, such discourses were explicitly tied to the project of nation building. Indeed, in describing the combination of the loudspeaker and radiotelephony that made such demonstrations possible, the Bell System patted itself on the back for its contribution to a 'time when a nation's head can speak simultaneously to many such audiences scattered over the length and breadth of the land. For science, manifesting itself in the telephone art, has united East and West' (anon. 1921d: 32). Self-serving though the Bell's rhetoric may have been, it is elegant and seems sincere: 
Back of it all lay a new conception of the American heart; a realization that this first public test of telephony's latest triumph had been a triumph for America itself; a deep and heartfelt feeling of thanks that there had been brought into being a means of binding together with newer and more intimate bonds, the Union which thousands of those who sleep at Arlington had died to preserve ... (ibid.: 33)

The ability of the loudspeaker to act in the service of nation building — to redefine the character and boundaries of America as an acoustic community - was obviously not lost on politicians or corporations.

We get a sense here of what's in a name: public address system. Ideas about 'publics' have specific histories, distinct from but overlapping with other understandings of audiences and groups such as crowds, mobs and masses (cf Butsch 2008). And if Harding's inaugural allayed fears about the impersonal disorder of the 'crowd' that concerned an earlier generation of analysts (e.g. Le Bon 1896; Simmel 1903; cf Tarde 1898), then discourse surrounding his funeral oration implicitly brushed off concerns about the passivity of the 'masses' that characterized social science and critical commentary of the day (e.g. Madge 1939; Lazarsfeld 1969; Adorno 2009). ${ }^{9}$ Instead, reports tended to extoll the virtues of the loudspeaker, not only as a tool for expanding and unifying the American acoustic public sphere, but also for increasing 'the enjoyability of modern life and the efficiency of modern business' (Mitchell 1931: 9).

Criticisms against amplification did of course arise. Some complained that the loudspeaker's 'lusty lungs' created an 'impenetrable din' in New York City (anon. 1930a), also known as the 'Big Babel' (Seymour 1928: 12). Others, in contrast to the utopian political view of the loudspeaker expressed by American corporations such as Bell, thought that amplifying political speeches in London's Hyde Park would be, simply, 'wearisome' (anon. 1928a: 425). While such complaints were part of broader discourses about noise as a social problem in the early twentieth century (cf Smilor 1979, Thompson 2002, Bijsterveld 2008, Schwartz 2011), it is also possible to mount a more ideological critique of the loudspeaker. For example, it would be possible to suggest, against the rhetoric surrounding the Harding oration, that the 'public' of public address is not the same as the Enlightenment public idealized by Richard Sennett (1977) and others (Eagleton 1981; Habermas 1984). For Sennett (ibid.: 261), the loudspeaker would not stimulate 'public' life; it would destroy it. The centrality of the orator, in Sennett's argument, aligns public address with control rather than dialogue, with passive spectatorship more than active witnessing. Such concerns represent something more than annoyance about noise or nostalgia for a public sphere that supposedly degenerated from coffeehouses to couchpotatoes. Indeed, while contemporary theorists may make more room for the 'publics' of public address by pointing to the importance of intersubjective aural interpellation in the formation and maintenance of everyday public life (Warner 2002; Ochoa Gauthier 2006; Born 2013), Sennett's argument takes on a chilling dimension when it comes to the use of the loudspeaker in establishing the Nazi regime. 'Without the loudspeaker', Hitler is said to have written, 'we would have never conquered Germany' (quoted in Attali 1985: 87; cf Birdsall 2007).

\footnotetext{
${ }^{9}$ For insightful analyses of several of these research programmes, see Clark (1969), Jowett et al. (1996), Hubble (2006), Hullot-Kentor (2009).
} 
What we see here are some of the ideologies that were projected onto - and through the loudspeaker during the 1920s. By 1930, Projection Engineering, one of the few trade papers dedicated to public address, was justly confident in the state of the art and its prospects: 'the socalled public-address system is being employed by all industries, amusements and in every walk of life' (Simons 1930: 18). A sound amplification industry had solidified and, despite the Depression, business was booming across the US (from New York airports to speaking cattle in Seattle) and around the world (in Mexican churches and Peruvian parks, Belgian palaces and Chilean theatres).$^{10}$ Of course, these technological, social and economic developments do not fully preexist or determine one other. Rather, they are co-produced within they dynamics of a listening formation, in the reciprocal and reconstructive frictions that exist between established conventions of acoustic mediation and the affordances of a new technological object.

\section{The Loudspeaker and Twentieth-Century Music}

If through the 1920s the applications — and controversies — of the loudspeaker were snowballing in public address generally, 'The cost of music', said a Western Electric advertisement in 1932, was 'tobogganing': 'Park-wide music at an operating cost of a few cents an hour - that is what you get with the Western Electric Music Reproducing System!' (Billboard 1994: 60). Western Electric was in the business of amplification, and so making a virtue of the fact that bands were no longer required for musical entertainment was in the company's best interest. Many musicians, though, were less enthusiastic. Take for example British critic Edwin Evans, lambasting the development of what he called 'Robot Music':

Already now there is no convincing reason why the proprietor of a popular dance-hall should engage a band at all. What with the enormous technical improvement in the process of recording, and the attention which wireless has caused to be concentrated on the problem of amplification, a combination of gramophone and loud-speaker can now be produced that gives the required volume and a tone-quality good enough to satisfy the taste of the average dancing public. (Evans 1928: 10)

This anxiety over the redundancy of the musician is a perennial concern regarding technological innovation in music history (cf Théberge 1997) and the actual industrial intricacies of these processes in the early twentieth century have been well documented by music scholars (e.g. Ehrlich 1989; Kraft 1996), especially in relation to what the Musicians' Union called the 'evil effect' of synchronized sound cinema (anon. 1931b; anon. 1930b). But Evans' worries about robot music stemmed from a particular application of amplification: 'a combination of gramophone and loud-speaker'. This application that sparked one of its most important controversies in the form of the jukebox.

Coin-operated music machines attained a level popularity in the phonograph parlours of the late nineteenth century; a combination of social and technological limitations, however,

${ }^{10}$ List of applications and contexts from Simons (1930: 18-20, 28). For a description of the emerging global sound empire in cinema, see Thompson (2004). On the relationship between the PA industry and the Depression, see McNicol (1931). 
meant that their popularity was short-lived. One important sociotechnical limitation was the necessity of ear tubes, which restricted listening to a handful of individuals at most. By the turn of the century, though, machines offered large amplifying horns, in addition to multiple disc selection and fully automated (if still hand-wound) operation, thus staving off the total extinction of coin-operated music machines. But the real boon — the big bang of the jukebox industry waited another twenty years:

Technology did not catch up with the jukebox until 1927, when several companies introduced electrically amplified instruments . . . Electrical amplification was the single most important technical improvement in the history of the machine. It created something entirely different from what had come before, and made possible everything that followed. Suddenly the jukebox was capable of competing with loud orchestras. It could entertain large groups of people in large halls, all at once, for a nickel. (Lynch and Henkin n.d.)

The repercussions of the loudspeaker in this context were swift and extensive: 'Soon, brothels, pool halls, Harlem social clubs, speakeasies, and southern roadside joints replaced their simple player pianos with jukeboxes' (Boehlert 1994: 94). Of course, the complaints registered in articles like 'Tinned Orchestras: Where the Robots Fail' (anon. 1931c) and 'Automaton Deputies: Dancing to "Unreal” Music' (J.M. 1930) indicate that neither jukeboxes nor sound recording more generally managed to fully replace live acts (cf Hazzard-Gordon 1990: 112).

Indeed, during the 1920s loudspeaker sound systems also began appearing in music venues to assist live musical performance. When they did, they were a source of uncertainty and controversy. One critic (Pearce 1929: 737) called the sound system 'inventive ability misapplied', wondering rhetorically why dancehall owners would 'engage a band of twelve when he can get more volume from one of five by using the amplifying device'. He continued, urging musicians 'to protest en bloc against using a device which is damaging their own and also many others' future prospects. Surely the talkies are proving a big enough menace without the need of any more clever (?) ideas' (ibid.).

Al Davison (1929: 737) defended his 'clever' invention, noting that critics had 'failed to appreciate the true position':

Mr. Pearce seems to have overlooked that the size of a dance band is seldom to be governed so much by the volume it can produce as by the variety of tone colours and effects it can feature, and its harmonic fullness. My amplifying device very efficiently increases the volume of each and every man in the band, but it cannot make, say, one saxophone, or (as another instance) one violin sound like a complete section, because each member of the section is playing a different part. (ibid.)

Davison was apparently genuine in his desire, not to put musicians out of work, but to enhance their tone - to offer an 'apparatus [which] reduces a musician's labour to that point at which he plays not only more sweetly, but more easily. There is no need for him to exert himself unduly by forcing his tone, as is so often the case when playing in large halls as we are' (ibid.: 738). In the end, there was truth to both sides of the argument: sound systems did facilitate a shift from the semi-orchestral backing of big bands to smaller ensembles, and they also facilitated new 
musical tones and new roles for voices and musical instruments. The controversy of the loudspeaker thus continued.

Crooning is one of the best known examples here. The softer, more delicate tones of this new, electrically amplified style of singing were resisted by critics and musicians (such as Al Jolson) trained in the tradition of acoustic singing. Established definitions of what constituted vocal talent and proper technique led to the condemnation of crooners as 'odious' and 'slushy', while those who saw a powerful voice as a marker of masculinity demeaned crooners as effeminate. One audience member went so far as to throw a grapefruit at Rudy Vallee during a 1931 concert, apparently protesting that Vallee wasn't a 'real man'. Crooning — and by extension the loudspeaker - thus participated in a renegotiation of gender norms in 1920s and 1930s music and culture (cf Frith 1986; McCracken 1999; Johnson 2000; Lockheart 2003).

From the late 1920s, when the guitar was first paired with an electrically amplified loudspeaker, it met with the same mixture of wonder and skepticism that was held for electricity more generally during the early twentieth century (cf Nye 1992): a young woman encountering the new instrument for the first time blurted 'Oh how marvelous!! Don't you get a shock when you touch it?' (Miller 1936: 13), while the patent office was unclear on whether the electric guitar was a musical instrument or an electronic device (Smith 1987: 17-19). Club owners worried that these newfangled guitars would blow fuses and disrupt their businesses, and so discouraged their use (Feather 1957: 130; cf Schmidt-Horning 2004). Old-guard guitarists and musicians resisted too, viewing 'the electric guitar as an oddity or gimmick' (Fliegler 1993: 12). As such, there were efforts to defend the instrument against the 'conjecture and ... endless barrage of questions from guitarists' that arose when it was first introduced (Mulcahy 1936: 14). Against the 'fallacy' that the electric guitar was simple to play and limited to clichés, there were efforts to establish it as an instrument that took serious practice and which was 'only as limited as the man who plays it' (ibid.). Another writer (Chambers 1939: 271) referred to electric guitars as 'instruments of torture' that 'made their appearance to crucify the ears of aesthetic musicians' - a comment which, though tongue-in-cheek (he nevertheless had 'a yen to own one'), still indicates something about the extent to which guitar purists reacted against amplification. As with crooning, the possibilities afforded by the electric guitar amplifier incited debate over the denigration of traditional musical values and playing techniques (cf Noonan 2008).

Owing partly to the curiosities and pretensions of musical modernism, the loudspeaker also took root in the world of art music. These roots were put down after Luigi Russolo, who could only have dreamed of the loudspeaker, and before Pierre Schaeffer, who needed it as a matter of course (not to mention the centrality of amplification to avant-garde composers such as John Cage and La Monte Young). In the interim, there was Leopold Stokowski. Stokowski famously extolled the virtues of electrically amplified sound, and of the new musical possibilities that came along with it. Nowhere was this more evident than in a series of demonstrations and performances stemming from Stokowski's collaboration with Bell Labs between 1930 and 1940. The goal here was to reproduce music in what was called 'auditory perspective', which involved advances in the frequency response of recorders and amplifiers, a new preoccupation with the spatialization of sound and hearing, and increasing the dynamic range of the loudspeaker system to match - and exceed - that of an orchestra (Fletcher et al. 1934; cf McGinn 1983). In an early report on the collaboration, Stokowski expressed his excitement about electrical amplification: 'The limitations of music are becoming less and less', he said, predicting that 'electrical-musical instruments' and 'sound films of the future' would 'be able to convey emotions higher than even thought — things subtle and intangible — almost psychic in their 
being' (anon. 1931d: 28). Whatever Stokowski is supposed to have meant by these oracular comments, his enthusiasm for the loudspeaker was echoed in the popular press.

Reporting on the 1933 Philadelphia-Washington demonstration for the National Academy of Sciences, the New York Tribune (1933) claimed to have witnessed 'something incomparably better than anything producible by unaided human hands', while the Philadelphia Inquirer (Martin 1933) thought the loudspeaker 'dazzlingly disclosed' 'vast and vital vistas for the whole uncharted future of symphonic and operatic performances'. Even the sober scientists at Bell Labs were given to dramatising the performance of their new loudspeaker system. Harvey Fletcher (1934: 9), for example, boasted that electrically amplified sound was 'of a character that may give even greater emotional thrills to music lovers than those experienced from the original music' (cf Kellogg 1929; Jewett 1933). The enthusiastic response to the loudspeaker and electrical amplification were thus shared widely. But, as with musical instruments and public address systems more generally, the enthusiasm was not universal.

The Stokowski-Bell demonstrations themselves were seen by some as 'spooky" (Kaempffert 1933), leaving audience members 'mystified and often terrified' (anon. 1934), and new loudspeaker-enabled performance practices incited anxiety among musicians, both in terms of the disruption of hierarchies and the possibility of technological redundancy. ${ }^{11}$ However, despite strong critical reactions such as these, sound systems and loudspeakers nevertheless became necessities in a variety of musical contexts during the early twentieth century including not only the contexts examined here, but also radio, cinema, television and others. Indeed, through the 1930s musicians' and hobbyists' magazines such as Down Beat and Radio Times were increasingly filled with advertisements for and articles about loudspeakers, public address systems and instrument amplifiers. Melody Maker (anon. 1934a: 2) was even scolding 'all those corny halls without microphones', describing 'a screaming need for amplifiers'. It was at this time that the loudspeaker achieved ubiquity in musical culture - a moment marked by a question posed matter-of-factly by Melody Maker in 1934(b: 4): 'What's a gig without an amplifier?'

\section{Conclusion: A Ubiquitous Music in the Air}

From mystery to ubiquity, novelty to necessity, impossibility to inevitability: the loudspeaker played a central role in numerous aesthetic, environmental and discursive transformations in early twentieth-century musical and acoustic culture. The technology achieved this centrality not by being straightforwardly requested and accepted by musicians and audiences but, rather, through a series of negotiations and realignments in which it was a source of both convenience and controversy, breakthrough and backlash.

In contrast to mythologies of rock and as a complement to research focused on midcentury developments, it is clear that sound reinforcement had in fact achieved a significant degree of technological and professional stability by the mid 1930s. During this period the

\footnotetext{
${ }^{11}$ Accounts of the auditory perspective audience as 'spellbound' but 'not a little terrified' were repeated after the 1940 demonstration (anon. 1940).
} 
loudspeaker also assumed a centrality in the cultural configuration of the acoustic subject. By playing on a normalized conception of hearing established in a discursive alignment of the acoustic sciences and industrial capitalism achieved for the purposes of telephony, this soundreproduction technology took on a defining role, not only in twentieth-century musical culture and the construction of the acoustic environment, but in the formation of modern listening more generally.

Although it is mundane and second-nature to hear a loudspeaker today, the forms and functions of the device were neither given nor neutral. Listening to a loudspeaker is a cultural practice that takes place within a listening formation, at the mutually modulating intersections of biography and biology, physics and psychology, technique and technology. We are reminded of this most obviously when amplified sound is powerful enough to chatter teeth and shatter eardrums (Stevens and Davis 1936; cf Jasen 2012; Cusick 2013). But, given the loudspeaker's 'perceptual technics' (Sterne 2012), it is no less true in the everyday contexts in which the modulations are less apparent. 


\section{Acknowledgments}

For feedback and conversation at many different stages of this work, thanks to Tom Everrett, Simon Frith, Paul Théberge and Patrick Valiquet. This research was supported by the Social Sciences and Humanities Research Council of Canada. 


\section{References}

Adams, Frank. 1987. Seeburg Jukeboxes: 60 Years of Fun, 1927-1987. Arlington: AMR.

Adorno, Theodor. 1990. 'The Curves of the Needle'. October 55: 48-55.

Adorno, Theodor. 2009. Current of Music: Elements of a Radio Theory. Cambridge: Polity.

Anon. n.d. The Use of Bell System Facilities in the Broadcasting of the Political Campaign of 1924 [AT\&T Archives and History Center (location 129-06-02)].

Anon. 1878a. 'The Aerophone'. New York Times (25 March): 4.

Anon. 1878b. 'The Aerophone'. 1878. London Figaro (13 April): 557, 559.

Anon. 1915. 'Magnavox Tested at the Park'. San Francisco Bulletin (11 December). Reprinted in Jensen (1975).

Anon. 1919. 'A Voice from the Sky'. Popular Science Monthly 95/1: 81.

Anon. 1920a. '200,000 May Hear Cox'. New York Times (23 August): 3.

Anon. 1920b. 'New Device to Enable 150,000 to Hear Cox'. New York Times (27 August): 11.

Anon. 1920c. 'All May Hear Harding Speech'. Washington Post (29 November): 14.

Anon. 1921a. 'Sound Amplifier Augments Religious Service'. Popular Mechanics 36/3: 324.

Anon. 1921b. 'A Telephonic Achievement Ranking With the Opening of the Transcontinental Line'. The Transmitter 9/3: 1-6.

Anon. 1921c. 'New York to Hear Harding Oration'. New York Times (06 November): 2.

Anon. 1921d. 'Our Tribute'. Long Lines (December): 26-33.

Anon. 1922a. 'Radio Megaphone is Large Enough for a Diving Platform'. Popular Mechanics 38/3: 343 .

Anon. 1922b. 'Transcontinental Radio Car Makes First Trip'. Popular Mechanics 38/4: 508.

Anon. 1924a. 'Noise of Electrons Heard by Human Ears'. Science News-Letter 5/191: 5-6.

Anon. 1924b. 'House Asked to Remove Loud-Speaking Apparatus'. Washington Post (20 May): 1. 
Anon. 1924c. 'Roar of Atoms Heard by Means of Radio'. New York Times (22 November): 2.

Anon. 1925. 'Millions to Hear Inaugural Address; Loud Speaker Here'. Washington Post (15 February): B7.

Anon. 1926a. 'Court to Install Loud Speaker to Stop Strain on Jurors' Ears'. New York Times (13 March): 19.

Anon. 1926b. 'Penn Installing Loud Speakers in Stadium So All Spectators Can Follow Every Play'. New York Times (13 April): 21.

Anon. 1928a. 'Radio in the Park'. Melody Maker 3/28: 425.

Anon. 1928b. 'Who Can Tell Us - ?'. Melody Maker 3/31: 868.

Anon. 1930a. 'Bedlam on Radio Row'. New York Times (25 May): 144.

Anon. 1930b. 'The Employment Market'. Melody Maker 5/49: 94-99.

Anon. 1931a. 'Entire City Can Hear World's Biggest Loudspeaker'. Popular Science Monthly 118/6: 68 .

Anon. 1931b. 'Europe’s Wiring-Up'. The Musicians’ Journal 9: 6.

Anon. 1931c. 'Tinned Orchestras: Where the Robots Fail'. Melody Maker 3/28: 804.

Anon. 1931d. 'Advance is Shown in Music Recording'. New York Times (10 December): 28.

Anon. 1933. 'The Super-Orchestra'. New York Tribune (14 April): n.p. [AT\&T Archives and History Center].

Anon. 1934a. 'All Those Corny Halls without Microphones: A Screaming Need for Amplifiers'. Melody Maker 10/36: 2.

Anon. 1934b. 'The Silent Partner'. Melody Maker 10/56: 4.

Anon. 1934c. 'Solidified Music Shakes a Building'. New York Times (25 January).

Anon. 1940. 'Sound Waves "Rock" Carnegie Hall as Enhanced Music is Played'. New York Times (10 April): 25.

Anon. 1963. 'Making PA Pay the Warren Way'. Public Address 6/1: 8-9.

Attali, Jaques. 1985. Noise: The Political Economy of Music. Minneapolis: University of Minnesota Press. 
Bennett, Tony. 2007. 'Making Culture, Changing Society: The Perspective of "Culture Studies"'. Cultural Studies 21/4-7: 610-629.

Beranek, Leo. 1954. 'Loudspeakers and Microphones'. Journal of the Acoustical Society of America 26/5: 618-29.

Bijsterveld, Karin. 2008. Mechanical Sound: Technology, Culture and Public Problems of Noise in the Twentieth Century. Cambridge: MIT Press.

Billboard. 1994. Billboard 100th Anniversary Issue, 1894-1994 (01 November).

Birdsall, Carolyn. 2007. 'Affirmative Resonances in the City? Sound, Imagination and Urban Space in Early 1930s Germany’. In Sylvia Mieszkowski et al., eds., Sonic Interventions, 57-86. Amsterdam: Rodopi.

Blesser, Barry and Linda Salter. 2007. Spaces Speak, Are You Listening? Cambridge: MIT Press.

Boehlert, Eric. 1994. 'Put Another Nickel In', in Billboard 100th Anniversary Issue, 1894-1994 (01 November): 93-98.

Boring, Edwin. 1942. Sensation and Perception in the History of Experimental Psychology. New York: Appleton-Century-Crofts.

Borwick, John, ed. 2001. Loudspeaker and Headphone Handbook. Oxford: Focal Press.

Bourdieu, Pierre. 1996. 'The Social Genesis of the Eye'. In Rules of Art: Genesis and Structure of the Literary Field. Stanford: Stanford University Press.

Born, Georgina. 2005. 'On Musical Mediation: Ontology, Technology, and Creativity', Twentieth-Century Music 2/1: 7-36.

Born, Georgina. 2011. 'Music and the Materialization of Identities'. Journal of Material Culture 16/4: 376-388.

Born, Georgina, ed. 2013. Music, Sound and Space: Transformations of Public and Private Experience. Cambridge: Cambridge University Press.

Born, Georgina, and David Hesmonhalgh, eds. 2000. Western Music and Its Others: Difference, Representation, and Appropriation in Music. Berkeley: University of California Press.

Butsch, Richard. 2008. The Citizen Audience: Crowds, Publics and Individuals. New York: Routledge.

Cameron, James. 1936. Sound Equipment, Motion Picture Projection, Public Address Equipment. Woodmont: Cameron Publishing. 
Chambers, Frank, 1939. 'How to Build a “Junkbox" Electric Guitar'. Radio-Craft 11/5: 271, 308-309.

Clark, Terry. 1969. 'Introduction'. In On Communication and Social Influence, Gabriel Tarde. Chicago: University of Chicago Press.

Clarke, Eric. 2007. 'The Impact of Recording on Listening'. Twentieth-Century Music 4/1: 4770 .

Coodley, Lauren. 2007. Napa: The Transformation of an American Town. San Francisco: Arcadia.

Cook, Nicholas et al., eds. 2009. The Cambridge Companion to Recorded Music. Cambridge: Cambridge University Press.

Cottrell, Stephen. 2012. The Saxophone. New Haven: Yale University Press.

Court, Stephen. 1984. 'Live Sound Evolution'. Studio Sound 26/6: 72-3.

Cusick, Susanne. 2013. 'Towards an Acoustemology of Detention in the 'Global War on Terror'". In Georgina Born, ed., Music, Sound and Space: Transformations of Public and Private Experience, 275-291. Cambridge: Cambridge University Press.

Davison, Al. 1929. ““Al” Replies'. Melody Maker 4/44: 737-738.

Devine, Kyle. 2013. 'Imperfect Sound Forever: Loudness Wars, Listening Formations, and the History of Sound Reproduction’. Popular Music 32/2: 159-176.

Dolan, Daniel. 2008. 'Cultural Noise: Amplified Sound, Freedom of Expression, and Privacy Rights in Japan'. International Journal of Communication 2: 662-690.

Dooley, M. Norman. 1932. 'Public Address in a Boxing Club'. Projection Engineering 4/6: 14.

Downes, Kieran. 2010. 'Perfect Sound Forever: Innovation, Aesthetics, and the Re-making of Compact Disc Playback'. Technology and Culture 51/2: 305-331.

Duncan, Ben. 1996. 'Live Sound'. In Paul Trynka, ed., Rock Hardware: 40 Years of Rock Instrumentation, 78-87. London: Balafon.

Eagleton, Terry. 1984. The Function of Criticism. London: Verso.

Eargle, John. 2003. Loudspeaker Handbook. Dordrecht: Kluwer.

Eccles, William. 1929. 'The New Acoustics'. Proceedings of the Physical Society 41/229: 231- 
39.

Ehrlich, Cyril. 1989. Harmonious Alliance: History of the Performing Rights Society. Oxford: Oxford University Press.

Eisenberg, Andrew. 2013. 'Islam, Sound, and Space: Acoustemology and Muslim Citizenship on the Kenyan Coast'. In Georgina Born, ed., Music, Sound and Space: Transformations of Public and Private Experience, 186-202. Cambridge: Cambridge University Press.

Eisenberg, Evan. 1987. The Recording Angel: Explorations in Phonography. New York: McGraw-Hill.

Engh, Barbara. 1999. 'After "His Master’s Voice”'. New Formations 38: 55-63.

Evans, Edwin. 1928. 'Robot Music'. The Dominant 1/4: 10.

Fagen, M., ed. 1975. A History of Engineering and Science in the Bell System: The Early Years (1875-1925). New York: Bell Telephone Laboratories.

Faulkner, Christopher. 1994. 'René Clair, Marcel Pagnol and the Social Dimension of Speech'. Screen 35/2: 157-170.

Feather, Leonard. 1957. The Book of Jazz: From Then Till Now. New York: Dell.

Fletcher, Harvey. 1933. 'An Acoustic Illusion Telephonically Achieved'. Bell Laboratories Record 11/10: 286-289.

Fletcher, Harvey. 1934. 'Auditory Perspective - Basic Requirements'. Transactions of the American Institute of Electrical Engineers 53/1: 9-11.

Fletcher, Harvey, et al. 1934. 'Symposium on Auditory Perspective'. Transactions of the American Institute of Electrical Engineers 53/1: 9-11, 216-19.

Fletcher, Harvey, and R. Wegel. 1922. 'The Frequency-Sensitivity of Normal Ears'. Physical Review 19/6: 553-65.

Fliegler, Ritchie. 1993. Amps! The Other Half of Rock 'n' Roll. Milwaukee: Hal Leonard.

Forman, Murray. 2012. One Night on TV is Worth Weeks at the Paramount: Popular Music on Early Television. Durham: Duke University Press.

Foucault, Michel. 1970. The Order of Things: An Archaeology of the Human Sciences. New York: Vintage.

Frith, Simon. 1986. 'Art versus Technology: The Strange Case of Popular Music'. Media, Culture and Society 8: 263-279. 
Frith, Simon. 1996. Performing Rites: On the Value of Popular Music. Cambridge: Harvard University Press.

Frith, Simon, and Lee Marshall, eds. 2004. Music and Copyright. New York: Routledge.

Frith, Simon, et al. 2010. 'Analyzing Live Music in the UK: Findings One Year into a ThreeYear Research Project'. Journal of the International Association for the Study of Popular Music 1/1: 30pp.

Gitelman, Lisa. 2000. Scripts, Grooves and Writing Machines: Representing Technology in the Edison Era. Chicago: University of Chicago Press.

Glover, Ralph. 1931. 'Sound Systems in Public Schools'. Projection Engineering 3/8: 19-20.

Gomery, Douglas. 2005. The Coming of Sound: A History. New York: Routledge.

Goodman, Steve. 2010. Sonic Warfare: Sound, Affect and the Ecology of Fear. Cambridge: MIT Press.

Gopinath, Sumanth. 2013. The Ringtone Dialectic: Economy and Cultural Form. Cambridge: MIT Press.

Green, I., and J. Maxfield. 1923. 'Public Address Systems'. The Bell System Technical Journal 2/2: 113-142.

Gunning, Tom. 1989. 'An Aesthetic of Astonishment: Early Film and the (In)credulous Spectator'. Art \& Text 34: 34-45.

Habermas, Jurgen. 1991. The Structural Transformation of the Public Sphere. Cambridge: MIT Press.

Hazzard-Gordon, Katrina. 1990. Jookin': The Rise of Social Dance Formations in AfricanAmerican Culture. Philadelphia: Temple University Press.

Henriques, Julian. 2003. 'Sonic Dominance and the Reggae Sound System'. In Michael Bull and Les Back, eds., The Auditory Culture Reader, 451-480. Oxford: Berg.

Henriques, Julian. 2011. Sonic Bodies: Reggae Sound Systems, Performance Techniques and Ways of Knowing. New York: Continuum.

Hirschkind, Charles. 2006. The Ethical Soundscape: Cassette Sermons and Islamic Counterpublics. New York: Columbia University Press.

Hubble, Nick. 2006. Mass-Observation and Everyday Life: Culture, History, Theory. New York: Macmillan. 
Howard, Deborah and Laura Moretti. 2009. Sound and Space in Renaissance Venice:

Architecture, Music, Acoustics. New Haven: Yale University Press.

Hullot-Kentor, Robert. 2009. 'Editor's Introduction'. In Current of Music, Theodor Adorno. Cambridge: Polity.

Hunt, Frederick. 1954. Electroacoustics. Cambridge: Harvard University Press.

Jasen, Paul. 2012. 'Bass: A Myth-Science of the Sonic Body'. PhD diss., Carleton University.

Jensen, Peter. 1975. The Great Voice. Clearwater: Havilah Press.

Jewett, Frank. 1933. 'Perfect Transmission and Reproduction of Symphonic Music in Auditory Perspective'. Bell Telephone Quarterly 12/2: 156-159.

Johnson, Bruce. 2000. The Inaudible Musicians: Gender, Jazz and Australian Modernity. Strawberry Hills: Currency Press.

Johnson, Bruce, and Martin Cloonan. 2008. The Dark Side of the Tune: Popular Music and Violence. Aldershot: Ashgate.

Jowett, Garth, et al. 1996. Children and the Movies: Media Influence and the Payne Fund Controversy. Cambridge: Cambridge University Press.

Kaempffert, Waldemar. 1933. 'New Tone Quality by Wire Achieved'. New York Times (13 April).

Kania, Andrew. 2008. 'Making Tracks: The Ontology of Rock Music'. Journal of Aesthetics and Art Criticism 64/4: 401-414.

Keightley, Keir. '1996. “Turn it Down!” She Shrieked: Gender, Domestic Space and High Fidelity, 1948-59’. Popular Music 15/2: 149-177.

Kellogg, Edward. 1929. 'New Musical Effects Produced by Electrical Means'. Projection Engineering 1/1: 41-42.

Kenney, William. 1999. Recorded Music and American Life: The Phonograph and Popular Memory, 1890-1945. Oxford: Oxford University Press.

Kittler, Friedrich. 1999. Gramophone, Film, Typewriter. Stanford: University of California Press.

Klapholz, Jesse. 1984. 'A Brief History of Loudspeakers'. $d b$ 18/7-8: 33. 
Korczynski, Marek, and Keith Jones. 2006. 'Instrumental music? The Social Origins of Broadcast Music in British Factories’. Popular Music 25/2: 145-164

Kraft, James. 1996. Stage to Studio: Musicians and the Sound Revolution, 1890-1950. Baltimore: Johns Hopkins University Press.

Lane, H. 1922. “"Dam is Breaking!”- Heard Four Miles'. Popular Mechanics 37/1: 9-12.

Lastra, James. 2000. Sound Technology and the American Cinema: Perception, Representation, Modernity. New York: Columbia University Press.

Latour, Bruno. 1999. Pandora's Hope: Essays on the Reality of Science Studies. Cambridge: Harvard University Press.

Latour, Bruno. 2005. Reassembling the Social: An Introduction to Actor-Network-Theory. Oxford: Oxford University Press.

Lazarsfeld, Paul. 1969. 'An Episode in the History of Social Research: A Memoir'. In The Intellectual Migration: Europe and America, 1930-1960, ed. Donald Fleming and Bernard Bailyn, 270-337. Cambridge: Belknap Press of Harvard University Press.

Le Bon, Gustave. 1896. The Crowd: A Study of the Popular Mind. New York: Macmillan.

Lee, Tong Soon. 1999. 'Technology and the Production of Islamic Space: The Call to Prayer in Singapore'. Ethnomusicology 43/1: 86-100.

Lockheart, Paula. 2003. 'An History of Early Microphone Singing, 1925-1939: American Mainstream Popular Singing at the Advent of Electronic Microphone Amplification'. Popular Music and Society 26/3: 367-385.

Lydon, Michael. 1974. Boogie Lightning: How Music Became Electric. New York: Dial Press. Lynch, Vincent, and Bill Henkin. n.d. Jukebox: The Golden Age. Berkeley: Lancaster-Miller.

M., J. 1930. ‘Automaton Deputies: Dancing to “Unreal” Music'. Melody Maker 5/60: 1019.

Madge, Charles. 1939. Britain by Mass-Observation. Harmondsworth: Penguin.

Maisonneuve, Sophie. 2009. L'invention du disque, 1877-1949: Genèse de l'usage des médias musicaux contemporains. Paris: Éditions des archives contemporaines.

Majeski, Brian, ed. 1990. The Music Trades 100th Anniversary Issue: A History of the US Music Industry. Englewood: Music Trades.

Martin, Linton. 1933. 'Themes and Variations'. Philadelphia Inquirer (16 April): n.p. [AT\&T 
Archives and History Center]

Martin, Peter. 1995. Sounds and Society: Themes in the Sociology of Music. Manchester: Manchester University Press.

Marvin, Carolyn. 1988. When Old Technologies Were New: Thinking about Electric Communication in the Late Nineteenth Century. New York: Oxford University Press.

Matheson, Carl, and Ben Caplan. 2011. 'Ontology', in The Routledge Companion to Philosophy and Music, ed. Theodore Gracyk and Andrew Kania. London: Routledge.

McCracken, Allison. 1999. 'God's Gift to Us Girls: Crooning, Gender, and the Re-Creation of American Popular Song, 1928-1933'. American Music 17/4: 365-395.

McGinn, Robert. 1983. 'Stokowski and the Bell Telephone Laboratories: Collaboration in the Development of High-Fidelity Sound Reproduction'. Technology and Culture 24/1: 38-75.

McNicol, Donald. 1931. 'Editorial'. Projection Engineering 3/12: 4.

Middleton, Richard. 2013. 'Faith, Hope, and the Hope of Love: On the Fidelity of the Phonographic Voice'. In Georgina Born, ed., Music, Sound, and Space: Transformations of Public and Private Experience, 292-311. Cambridge: Cambridge University Press.

Miller, Jack. 1936. 'Steel Guitar has Place in Modern Orchestra'. Down Beat (June): 13.

Mills, Mara. 2009. 'When Mobile Communication Technologies Were New'. Endeavour 33(4): 140-146.

Mitchell, Gordon. 1931. 'Applying Public-Address Equipment for Indoor Use'. Projection Engineering 3/8: 7-9.

Mitchell, Gordon. 1932. 'Public-Address and Radio Distribution System for Colleges'. Projection Engineering 4/3: 11-12.

Mowitt, John. 1987. 'The Sound of Music in the Era of Its Electronic Reproducibility'. In Richard Leppert and Susan McClary, eds., Music and Society, 173-197. Cambridge: Cambridge University Press.

Mulcahy, Bob. 1936. 'The True Value of the Electric Guitar'. Down Beat (October): 14.

Newell, Philip, and Keith Holland. 2007. Loudspeakers: For Music Recording and Reproduction. Amerstdam: Elsevier.

Noonan, Jeffrey. 2008. The Guitar in America: Victorian Era to Jazz Age. Jackson: University Press of Mississippi. 
Nye, David. 1992. Electrifying America: Social Meanings of a New Technology, 1880-1940. Cambridge: MIT Press.

Ochoa Gauthier, Ana Maria. 2006. 'Sonic Transculturation, Epistemologies of Purification, and the Aural Public Sphere in Latin America'. Social Identities 12/6: 803-825.

Osborne, Richard. 2012. Vinyl: A History of the Analogue Record. Farnham: Ashgate.

Pearce, Frank. 1929. 'Misapplied Inventiveness'. Melody Maker 4/44: 737.

Percival, Mark. 2011. 'Stone Deaf Forever: Discourses of Live Loudness in Popular Music Journalism'. Paper presented at The Business of Live Music, Edinburgh (UK), April-May.

Piekut, Benjamin. 2011. Experimentalism Otherwise: The New York Avant-Garde and Its Limits. Berkeley: University of California Press.

Pinch, Trevor, and Karin Bijsterveld. 2003. “'Should One Applaud?”: Breaches and Boundaries in the Reception of New Technology in Music'. Technology and Culture 44/3: 536-559.

Pinch, Trevor, and Frank Trocco. 2002. Analog Days: The Invention and Impact of the Moog Synthesizer. Cambridge: MIT Press.

Pridham, Edwin. 1918. 'Telephone System'. US Patent 1,356,403 (07 May).

Radovac, Lilian. 2011. 'The "War on Noise”: Sound and Space in La Guardia's New York'. American Quarterly 63/3: 733-760.

Rice, Chester, and Edward Kellogg. 1925. 'Notes on the Development of a New Type of Hornless Loud Speaker'. Transactions of the AIEE 44: 461-480.

Rothenbuhler, Eric, and John Durham Peters. 1997. 'Defining Phonography: An Experiment in Theory'. The Musical Quarterly 81/2: 242-64.

Schafer, R. Murray. 1994. The Soundscape: Our Sonic Environment and the Tuning of the World. Rochester: Destiny.

Schmidt, Leigh Eric. 2000. Hearing Things: Religion, Illusion and the American Enlightenment. Cambridge: Harvard University Press.

Schmidt-Horning, Susan. 2004. 'Recording: The Search for Sound'. In André Millard, ed., The Electric Guitar: A History of an American Icon, 105-22. Baltimore: Johns Hopkins University Press.

Schwartz, Hillel. 2011. Making Noise: From Babel to the Big Bang and Beyond. New York: Zone Books. 
Sennett, Richard. 1977. The Fall of Public Man. Toronto: Random House.

Sewald, Ronda. 2011. 'Forced Listening: The Contested Use of Loudspeakers for Commercial and Political Messages in the Public Soundscape'. American Quarterly 63/3: 761-780.

Seymour, G. 1928. 'Radio Row in New York'. Washington Post (29 August): 12.

Shiga, John. Forthcoming. 'Deepwater Surveillance: Multichannel Sound and the Control of Undersea Space'. In Kyle Devine, Tom Everrett and Paul Théberge, eds., Living Stereo:

Histories and Cultures of Multichannel Sound. New York: Continuum/Bloomsbury.

Simmel, Georg. 1964 (1903). 'The Metropolis and Mental Life'. In The Sociology of Georg Simmel. New York: The Free Press.

Simons, Norman. 1930. 'Sound Amplification as a Business'. Projection Engineering 2/4: 18-20, 28.

Smilor, Raymond. 1979. 'Personal Boudnaries in the Urban Environment: The Legal Attack on Noise, 1865-1930'. Environmental Review 3/3: 24-36.

Smith, Richard. 1987. The History of Rickenbacker Guitars. Anaheim: Centerstream.

Sterne, Jonathan. 2003. The Audible Past: Cultural Origins of Sound Reproduction. Durham: Duke University Press.

Sterne, Jonathan. 2006. 'The MP3 as Cultural Artifact'. New Media \& Society 8/5: 825-842.

Sterne, Jonathan. 2007. 'Media or Instruments? Yes'. Offscreen 11/8-9: 18pp.

Sterne, Jonathan. 2012. MP3: The Meaning of a Format. Durham: Duke University Press.

Sterne, Jonathan. 2013. 'What the Mind's Ear Doesn't Hear'. In Georgina Born, ed., Music, Sound and Space: Transformations of Public and Private Experience, 111-127. Cambridge: Cambridge University Press.

Stevens, Stanley, and Hallowell Davis. 1936. 'Psychophysiological Acoustics: Pitch and Loudness'. Journal of the Acoustical Society of America 8/1: 1-13.

Straw, Will. 2010. 'Cultural Production and the Generative Matrix'. Cultural Sociology 4/2: 209216.

Talbot, Michael ed. 2000. The Musical Work: Reality or Invention? Liverpool: Liverpool University Press.

Tarde, Gabriel. 1969 (1898). 'The Public and the Crowd'. In On Communication and Social 
Influence. Chicago: University of Chicago Press.

Théberge, Paul. 1997. Any Sound You Can Imagine: Making Music / Consuming Technology. Middletown: Wesleyan University Press.

Théberge, Paul. 2001. “Plugged In”: Technology and Popular Music'. In Simon Frith et al., eds., The Cambridge Companion to Pop and Rock, 3-25. Cambridge: Cambridge University Press. 325.

Thompson, Emily. 2002. The Soundscape of Modernity: Architectural Acoustics and the Culture of Listening in America, 1900-1933. Cambridge: MIT Press.

Thompson, Emily. 2004. 'Wiring the World: Acoustical Engineers and the Empire of Sound in the Motion Picture Industry, 1927-1930'. In Veit Erlmann, ed., Hearing Cultures: Essays on Sound, Listening, and Modernity, 191-210. Oxford: Berg.

Van-Ashe Radio. 1929-1930. Radio Catalogue. St Louis: Van-Ashe Radio.

Waksman, Steve. 1999. Instruments of Desire: The Electric Guitar and the Shaping of Musical Experience. Cambridge: Harvard University Press.

Waksman, Steve. 2009. This Ain't the Summer of Love: Conflict and Crossover in Heavy Metal and Punk. Berkeley: University of California Press.

Warner, Michael. 2002. 'Publics and Counterpublics'. Quarterly Journal of Speech 88/4: 413425.

Warren, Frank. 1965. 'Those Early Days'. Public Address Engineers Journal 8/3: 56-73.

Western Electric. n.d. (ca. 1922). Amplifying the Voice: A Voice Amplifying System for the Nation's Capital. [AT\&T Archives and History Center (location: 5506 01)].

Wilson, P. 1929. Modern Gramophones and Electrical Reproducers. London: Cassell.

Wurtzler, Steve. 2007. Electric Sounds: Technological Change and the Rise of Corporate Mass Media. New York: Columbia University Press. 